\title{
PENGARUH JENIS FORMULASI JAMUR ENTOMOPATOGEN Beauveria bassiana TERHADAP PERTUMBUHAN SPORA DAN KEMATIAN KUTUDAUN KEDELAI (Aphis glycines Matsumura)
}

\author{
Sasha Putri Pertiwi, Rosma Hasibuan \& Lestari Wibowo \\ Jurusan Agroteknologi Fakultas Pertanian Universitas Lampung \\ Jl. Prof. Soemantri Brodjonegoro, No 1 Bandar Lampung 35145 \\ E-mail: sasharnandaaa@gmail.com
}

\begin{abstract}
ABSTRAK
Kutudaun kedelai Aphis glycines (Hemiptera: Aphididae) merupakan hama yang selalu ada di pertanaman kedelai dan menimbulkan kerugian yang sangat berarti bagi petani. Jamur Beauveria bassiana merupakan agensia hayati yang memiliki berbagai kelebihan diantaranya mempunyai kapasitas reproduksi yang tinggi, dapat membentuk spora yang tahan lama di alam, ramah lingkungan, serta memiliki patogenesis yang tinggi terhadap hama sasaran. Penelitian ini bertujuan untuk mengetahui pengaruh jenis formulasi jamur entomopatogen Beauveria bassiana terhadap pertumbuhan spora dan kematian kutudaun kedelai (Aphis glycines Matsumura). Penelitian ini dilakukan di laboratorium yang terdiri atas 3 percobaan: kerapatan konidia, viabilitas spora dan patogenesitas kutudaun. Jenis perlakuan adalah formulasi cair (F0), formulasi kering (F1), Formulasi pasta-1 dan formulasi pasta-2. Penelitian ini disusun menggunakan Rancangan Acak Lengkap (RAL) dan masingmasing perlakuan diulang empat kali. Data yang didapat dianalisis ragam dan dan dilanjutkan dengan uji BNT dengan taraf nyata 5\%. Kesimpulan dari penelitian ini adalah Kerapatan konidia B.bassiana berbeda nyata antar formulasi yang diuji. Kerapatan konidia B.bassiana formulasi cair (F0) lebih tinggi dibandingkan formulasi pasta2 (F3) dan formulasi pasta1 (F2). Namun, formulasi cair (F0) tersebut tidak berbeda nyata dengan formulasi kering (F1). Viabilitas konidia B.bassiana berbeda nyata antar formulasi yang diuji. Viabilitas konidia $B$. bassiana formulasi kering (F1) lebih tinggi dibandingkan formulasi pasta1 (F2), formulasi cair (F0) dan formulasi pasta2 (F3). Aplikasi B.bassiana beberapa dari formulasi kering (F1) menyebabkan mortalitas kutudaun tertinggi (92\%) dibandingkan formulasi cair (F0), formulasi pasta1 (F2) dan formulasi pasta2 (F3).
\end{abstract}

Kata kunci: Aphis glycines, Beauveria bassiana, kerapatan konidia, patogenesitas, viabilitas.

\section{PENDAHULUAN}

Kedelai (Glycine max L) merupakan salah satu sumber protein nabati bagi penduduk Indonesia maupun penduduk dunia. Di Indonesia kedelai banyak digunakan sebagai bahan baku pembuatan tempe, kecap, susu kedelai, dan tauco. Namun, produksi kedelai nasional hingga saat ini belum dapat memenuhi kebutuhan dalam negeri sehingga masih harus mengimpor. Tidak terpenuhinya kebutuhan kedelai nasional disebabkan oleh rendahnya produktivitas tanaman. Salah satu penyebab rendahnya produktivitas tanaman adalah serangan hama kutudaun kedelai Aphis glycines (Hemiptera: Aphididae).

Hama A. glycines merupakan hama yang selalu ada di pertanaman kedelai dan menimbulkan kerugian yang sangat berarti bagi petani. Hama A. glycines dapat menimbulkan kerusakan pada tanaman baik secara langsung maupun secara tidak langsung. Kerusakan langsung terjadi karena kutudaun tersebut mengisap cairan tanaman, sehingga pertumbuhan tanaman terhambat dan daun mengeriting. Sedangkan kerusakan tidak langsung timbul akibat tertutupinya permukaan daun tanaman oleh embun jelaga, sehingga proses fotosisntesis tanaman terhambat (Ekawati et al., 2013).

Pada umumnya upaya pengendalian hama kedelai ini berdasarkan atas konsep pengendalian hama terpadu (PHT). Dalam sistem PHT, pengendalian hama tanaman berorientasi kepada stabilitas ekosistem dan efisiensi ekonomi. Populasi hama diusahakan dalam keadaan dinamis dan berfluktuasi pada kondisi seimbang (Suwahyono, 2010). Secara alamiah, agensia hayati merupakan komponen utama dalam pengendalian alami yang dapat mempertahankan semua organisme pada ekosistem tersebut berada dalam keadaan seimbang. Beberapa jenis agensia hayati yang sudah dapat dikembangkan antara lain parasitoid, predator, agens antagonis dan entomopatogen terdiri atas virus, bakteri, nematoda, dan jamur (Herlinda, 2008).

Salah satu agensia hayati yang potensial sebagai sarana pengendalian hama adalah jamur entomopatogen Beauveria bassiana. Jamur B. bassiana dikenal 
sebagai penyebab penyakit white muscardine karena miselia dan konidia (spora) yang dihasilkan berwarna putih serta berbentuk bulat sampai oval. Jamur $B$. bassiana mempunyai beberapa kelebihan diantaranya mempunyai kapasitas reproduksi yang tinggi, dapat membentuk spora yang tahan lama di alam, ramah lingkungan, serta memiliki patogenesis yang tinggi terhadap hama sasaran (Herlinda, 2008). Setiap serangga yang terinfeksi $B$. bassiana akan efektif menjadi sumber infeksi bagi serangga sehat di sekitarnya. Selain itu, jamur entomopatogen $B$. bassiana memiliki kemampuan penetrasinya yang tinggi pada tubuh serangga. Agar jamur B. bassiana dapat disimpan dalam jangka waktu yang lama, praktis, dan dapat lebih mudah diaplikasikan maka dibuat beberapa jenis formulasi (Suwahyono, 2010).

Pembuatan beberapa jenis formulasi jamur $B$. bassiana dilakukan dengan cara menumbuhkan jamur pada media beras, kemudian setelah masa inkubasi selama \pm 2 minggu beras yang telah ditumbuhi jamur $B$. bassiana dikeringkan di dalam lemari pendingin pada suhu $5-15^{\circ} \mathrm{C}$ selama 12 hari, setelah itu dihaluskan dengan cara diblender lalu diayak. Media yang telah halus kemudian ditambahkan bahan pembawa (Suwahyono, 2010). Produksi dan formulasi jamur entomopatogen telah banyak diteliti, khususnya jamur Beauveria bassiana dan Metharizium anisopliae. Formulasi bentuk produk pun banyak dikembangkan oleh para peneliti berdasarkan latar belakang kepentingannya (Suwahyono, 2010).

Berdasarkan penelitian Eyal et al. (1994) Pembuatan formula dalam bentuk butiran mampu bertahan lama saat penyimpanan. Berdasarkan penelitian Morales dan Rochling (1998) mengembangkan produk formula dalam bentuk granula yang mudah larut di dalam air. Berdasarkan penelitian Quimby et al. (2002) membuat bentuk produk yang sama yaitu granula, dengan sedikit kelebihan berupa penambahan bahan untuk stabilisasi dan mengembangkan formula bentuk gel, yang dapat digunakan untuk semua jenis bahan pestisida, baik agensia hayati dan kimia.
Merujuk pada hasil-hasil penelitian tersebut, dapat dilakukan pengembangan metode produksi dan formulasi yang lebih tepat untuk kebutuhan di Indonesia, khususnya jika akan dikembangkan di sentra-sentra pertanian dalam bentuk industri kecil dan menengah. Pemilihan bahan baku medium produksi dan komposisi formulasi diupayakan menjadi solusi (Suwahyono dan Wahyudi, 2008). Penelitian ini bertujuan untuk menguji komposisi beberapa formulasi yang berbeda dalam menghasilkan pertumbuhan jamur entomopatogen $B$. bassiana yang paling efektif dan untuk menguji formulasi B. bassiana dalam mempengaruhi efektivitas jamur dalam mengendalikan kutudaun kedelai (Aphis glycines Matsumura).

\section{BAHAN DAN METODE}

Penelitian ini dilaksanakan pada bulan Oktober 2014 - Agustus 2015 di Laboratorium Hama Tumbuhan Jurusan Agroteknologi Fakultas Pertanian Universitas Lampung dan Laboratorium Lapangan Terpadu Fakultas Pertanian Universitas Lampung. Alat-alat yang digunakan pada penelitian ini adalah autoclave, kompor, mikroskop, timbangan eletrik, panci, blender, ayakan, nampan, plastik tahan panas, alumunium foil, karet gelang, steples, rotamixer, tabung reaksi, cawan petri, erlenmeyer, botol film, bunsen, gelas ukur, sprayer, jarum ose, mikropipet, pinset, kertas label, alat tulis, dan kamera. Bahan-bahan yang digunakan pada penelitian ini adalah SDA (Sabouroud Dextrose Agar), isolate jamur B. bassiana, beras, aquades, tissue, alkohol $70 \%$, tepung biomassa spora, tepung jagung, glycerol, sukrose, tween80 , kaolin, zeolit, propilen glycol, Na-alginat, urea, dan air. Penelitian ini disusun secara Rancangan Acak Lengkap (RAL) dengan 4 perlakuan dan 4 kali ulangan (Tabel 1). Data pertumbuhan jamur dan patogenesitas kutudaun diuji dengan sidik ragam (analysis of variance $=$ ANOVA) dan dilanjutkan dengan uji Beda Nyata Terkecil (BNT) pada taraf 5\% dengan menggunakan perangkat SAS. Persiapan penelitian diawali dengan Perbanyakan dan pemeliharaan serangga uji (Aphis

Tabel 1. Deskripsi perlakuan komposisi formulasi kering dan formulasi pasta jamur B. bassiana

\begin{tabular}{|c|c|c|}
\hline Perlakuan & Jenis Formulasi & Deskripsi \\
\hline F0 & Formulasi Cair & Komposisi tepung biomassa spora $40 \mathrm{~g}+$ Air $60 \mathrm{ml}$ \\
\hline $\mathrm{F} 1$ & Formulasi Kering & $\begin{array}{l}\text { Komposisi tepung biomassa spora } 40 \mathrm{~g}+\text { Tepung jagung } 20 \mathrm{~g}+\text { Kaolin } \\
20 \mathrm{~g}+\text { Zeolit } 20 \mathrm{~g}\end{array}$ \\
\hline $\mathrm{F} 2$ & Formulasi Pasta1 & $\begin{array}{l}\text { Komposisi tepung biomassa spora } 40 \mathrm{~g}+ \\
\text { Glycerol } 1,6 \mathrm{~g}+\text { Na-alginat } 1,7 \mathrm{~g}+\text { Urea } 0,2 \mathrm{~g}+\text { Air } 56,5 \mathrm{ml}\end{array}$ \\
\hline F3 & Formulasi Pasta2 & $\begin{array}{l}\text { Komposisi tepung biomassa spora } 40 \mathrm{~g}+\text { Glycerol 9,8 } \mathrm{g}+\text { Tween- } 80 \\
0,01 \mathrm{~g}+\text { Sukrose } 2,39 \mathrm{~g}+\text { Air } 47,8 \mathrm{ml}\end{array}$ \\
\hline
\end{tabular}


glycines). Serangga dikembangkan dan dipelihara pada tanaman kedelai yang ditanam di Lahan Percobaan BPTP Natar pada waktu yang bersamaan. Pembuatan media SDA (Sabouroud Dextrose Agar) dilakukan dengan komposisi $40 \mathrm{~g}$ dextrose, $15 \mathrm{~g}$ agar, $5 \mathrm{~g}$ kasein, $10 \mathrm{~g}$ pepton, dan 1 1iter air aquades. Semua bahan tersebut dicampur dan dimasukan ke dalam tabung Erlenmeyer kemudian ditutup dengan alumunium foil, dikencangkan dengan karet gelang, dan dibungkus dengan plastik tahan panas. Setelah itu, semua bahan tersebut diautoklaf selama 2 jam. Kemudian media tersebut diangkat dan didiamkan hingga dingin. Selanjutnya, media yang telah siap pakai dituang ke masing-masing cawan petri dalam ruangan steril (Laminar Air Flaw). Isolat B. bassiana berasal dari Tegineneng diisolasi untuk mempertahankan isolat murni. Isolasi dilakukan di Laboratorium Penyakit Tumbuhan Fakultas Pertanian Universitas lampung dengan menggunakan media SDA (Sabouroud Dextrose Agar) kemudian dilakukan inkubasi selama 30 hari.

Perbanyakan $B$. bassiana dilakukan dengan menggunakan media beras yang telah disiapkan dicuci sampai bersih, kemudian disiram dengan air mendidih. Setelah itu beras tersebut dikukus hingga setengah beras matang selama 15 menit, kemudian diangkat dan dikering anginkan. Setelah beras dingin, beras dimasukkan sebanyak $100 \mathrm{~g}$ ke dalam plastik tahan panas. Untuk mendapatkan beras yang baik kantong tersebut dipadatkan dan posisikan pada bagian bawah plastik, dan bagian atas plastik yang telah terisi dirapihkan dan digulung lalu disteples. Beras tersebut disterilkan dengan autoklaf pada suhu $120^{\circ} \mathrm{C}$, tekanan 1 atm selama 20 menit. Setelah di autoklaf beras diangkat dan dikeringkan. Kemudian B. bassiana diinkubasi selama 2-3 minggu. Pembuatan formulasi B. bassiana tepung biomassa spora jamur $B$. bassiana dilakukan dengan cara mengeringkan jamur $B$. bassiana yang tumbuh pada media beras. Pengeringan dilakukan di dalam lemari pendingin pada suhu $10^{\circ} \mathrm{C}$ selama 12 hari. Setelah kering lalu dihaluskan dengan cara diblender dan diayak sehingga jadilah tepung halus yang banyak mengandung biomassa spora. Masing-masing formulasi dicampurkan di dalam cawan.

Perhitungan kerapatan konidia B. Bassiana. Untuk mengetahui kandungan spora $B$. bassiana diambil $1 \mathrm{~g}$ formulasi kering dari masing-masing perlakuan yang berupa bubuk halus dan dimasukan ke dalam $10 \mathrm{ml}$ aquades. Setelah itu dihomogenkan dengan rotamixer, kemudian dilakukan pengenceran $10^{-1}$ lalu dihitung jumlah sporanya dengan bantuan alat Haemocytometer. Dengan cara meneteskan suspensi B. bassiana dengan pengenceran $10^{-1} \mathrm{ke}$ atas permukaan Haemocytometer menggunakan mikropipet, kemudian permukaan Haemocytometer ditutup dengan gelas objek, sehingga suspense mengalir ke bawah kaca obyek dan mengisi ruang hitung. Lalu jumlah konidia dihitung dalam 5 kotak ukuran sedang. Semua pekerjaan perhitungan dilakukan di bawah mikroskop binokuler dengan perbesaran $10 \times 40$. Menurut Pujiastuti et al. (2006), kerapatan spora dihitung dengan rumus :

$$
\text { Kerapatan spora }=\frac{\text { rata }- \text { rata jumlah spora }}{0,04 \times 0,1} \times 10^{3}
$$

Keterangan:

0,04 = Luas kotak sedang Haemocytometer

0,1 = Kedalaman Haemocytometer

$10^{3}=$ Perhitungan per $\mathrm{ml}$

Pengujian viabilitas $B$. bassiana. Jamur $B$. bassiana diambil sebanyak $1 \mathrm{~g}$ dari masing-masing perlakuan dan dimasukkan ke dalam tabung reaksi yang berisi $10 \mathrm{ml}$ aquades. Kemudian media tersebut diinkubasi dalam ruangan isolasi selama $24 \mathrm{jam}$. Setelah itu campuran spora tersebut dihomogenkan dengan rotamixer, setelah homogen dilakukan pengenceran $10^{-1}$ lalu baru jumlah sporanya dihitung dengan bantuan alat Haemocytometer. Rata-rata konidia yang tumbuh dan tidak tumbuh dihitung di bawah mikroskop binokuler dengan perbesaran $10 \times 40$. Menurut Pujiastuti et al. (2006), persentase rata-rata perkembangan dihitung dengan rumus :

$$
\mathrm{V}=\frac{\mathrm{g}}{\mathrm{g}+\mathrm{u}} \times 100
$$

Keterangan :

$\mathrm{V}=$ Persentase konidia yang berkecambah

$\mathrm{g}=$ Jumlah rata-rata konidia yang berkecambah

$\mathrm{u}=$ Jumlah rata-rata konidia yang tidak berkecambah

Pengujian Patogenesitas Beberapa Formulasi $B$. bassiana. Biakan formulasi kering jamur B. bassiana diambil sebanyak $1 \mathrm{~g}$, kemudian diencerkan dengan 10 $\mathrm{ml}$ air steril dalam tabung reaksi lalu dikocok dengan menggunakan rotamixer hingga tercampur merata. Setelah itu, suspensi jamur disemprotkan pada serangga uji sebanyak $\pm 5 \mathrm{ml}$ dengan menggunakan modifikasi handsprayer (volume $20 \mathrm{ml}$ ). Suspensi jamur disemprotkan pada tanaman kedelai yang terserang kutudaun sebanyak 25 ekor. Tanaman dipotong sepanjang $10 \mathrm{~cm}$ dimasukkan ke dalam gelas plastik yang telah diisi oleh air sebanyak $10 \mathrm{ml}$. Pengamatan dilakukan setiap hari selama 7 hari setelah aplikasi atau sampai serangga uji mati. Menurut Malau et al. (2010), 
persentase mortalitas dihitung dengan menggunakan rumus :

$$
\mathrm{PI}=\frac{\sum \mathrm{n}}{\sum \mathrm{N}} \times 100
$$

Keterangan :

$\mathrm{PI}=$ Persentase infeksi $(\%)$

$\mathrm{n}=$ Serangga yang mati (ekor)

$\mathrm{N}$ = Jumlah serangga yang diuji (ekor)

\section{HASIL DAN PEMBAHASAN}

Hasil percobaan tentang jenis formulasi entomopatogen B. bassiana terhadap kerapatan konidia menunjukkan bahwa jenis formulasi entomopatogen $B$. bassiana yang diuji berpengaruh nyata terhadap kerapatan konidia B. bassiana (Tabel 2).Kerapatan konidia $B$. bassiana formulasi cair (F0) dengan komposisi tepung biomassa spora $40 \mathrm{~g}+$ air $60 \mathrm{ml}$, nyata lebih besar $\left(9 \times 10^{5} / \mathrm{ml}\right)$ dibandingkan dengan formulasi pasta1 (F2) dengan komposisi tepung biomassa spora $40 \mathrm{~g}+$ glycerol $1,6 \mathrm{~g}+$ Na-alginat $1,7 \mathrm{~g}+$ urea $0,2 \mathrm{~g}+$ air $56,5 \mathrm{ml}\left(7,3 \times 10^{5} / \mathrm{ml}\right)$ dan formulasi pasta2 (F3) dengan komposisi tepung biomassa spora $40 \mathrm{~g}+$ Glycerol 9,8 $\mathrm{g}+$ Tween-80 0,01 $\mathrm{g}+$ Sukrose 2,39 $\mathrm{g}+$ Air 47,8 ml $\left(6,5 \times 10^{5} / \mathrm{ml}\right)$. Namun, formulasi cair (F0) tersebut tidak berbeda nyata dengan formulasi kering (F1) dengan komposisi tepung biomassa spora $40 \mathrm{~g}+$ tepung jagung $20 \mathrm{~g}+$ kaolin $20 \mathrm{~g}+$ zeolit $20 \mathrm{~g}\left(7,8 \times 10^{5} / \mathrm{ml}\right)$. Menurut Hasyim et al. (2005) konidia jamur entomopatogen yang berada dalam formulasi cair cenderung lebih tinggi dibandingkan pada media padat. Pada formulasi cair (F0) tidak ditambahkan bahan-bahan pembawa seperti formulasi yang lainnya, formulasi cair (F0) hanya mengandung biomassa spora $40 \mathrm{~g}$ dan air $60 \mathrm{ml}$ sehingga spora dapat terlihat jelas lebih banyak dibandingkan formulasi lain yang ditambahkan bahan-bahan pembawa seperti tepung jagung, glycerol, sukrose, tween-80, kaolin, zeolit, propilen glycol, Na-alginat, dan urea yang menjadikan formulasi lebih padat dan spora yang ada tidak terlihat dengan jelas dan lebih sedikit dibandingkan formulasi cair (F0). Hal tersebut diduga karena banyak konidia yang melekat pada bahan pembawa.

Hasil percobaan beberapa jenis formulasi entomopatogen $B$. bassiana terhadap viabilitas konidia menunjukkan bahwa beberapa formulasi entomopatogen $B$. bassiana yang diuji berpengaruh sangat nyata terhadap viabilitas konidia $B$. bassiana (Tabel 2). Uji viabilitas konidia $B$. bassiana dilakukan untuk mengetahui seberapa besar jumlah konidia berkecambah dalam jangka waktu 24 jam setelah inokulasi. Hal ini perlu dilakukan untuk menentukan potensi jamur $B$. bassiana menginfeksi serangga inang. Viabilitas konidia B. bassiana formulasi kering (F1) dengan komposisi tepung biomassa spora $40 \mathrm{~g}+$ tepung jagung $20 \mathrm{~g}+$ kaolin $20 \mathrm{~g}+$ zeolit $20 \mathrm{~g}(68,43 \%)$ sangat berbeda nyata dengan formulasi cair (F0) dengan komposisi tepung biomassa spora $40 \mathrm{~g}+$ air $60 \mathrm{ml}(41,36 \%)$, formulasi pasta2 (F3) dengan komposisi tepung biomassa spora $40 \mathrm{~g}+$ glycerol 9,8 $\mathrm{g}+$ tween-80 0,01 $\mathrm{g}+$ sukrose 2,39 $\mathrm{g}+$ air $47,8 \mathrm{ml}(46,18 \%)$ dan formulasi pastal (F2) dengan komposisi tepung biomassa spora $40 \mathrm{~g}+$ glycerol

Tabel 2. Nilai tengah kerapatan dan viabilitas konidia beberapa formulasi jamur entomopatogen $B$. bassiana

\begin{tabular}{|c|c|c|}
\hline Perlakuan & $\begin{array}{c}\text { Kerapatan konidia } \\
\left(10^{5} \text { konidia/ml }\right)\end{array}$ & Viabilitas konidia (\%) \\
\hline Formulasi Cair (F0) ${ }^{(\mathrm{y})}$ & $9 \mathrm{a}$ & $41,360 \mathrm{c}$ \\
\hline Formulasi Kering (F1) & 7,8 & $68,443 \mathrm{a}$ \\
\hline Formulasi Pasta1 (F2) & 7,3 & $50,952 \mathrm{~b}$ \\
\hline Formulasi Pasta2 (F3) & 6,5 & $46,181 \mathrm{bc}$ \\
\hline $\operatorname{Pr}>F$ & $0,008^{*(\mathrm{x})}$ & $0,001 * *(\mathrm{x})$ \\
\hline BNT & 1,287 & 7,393 \\
\hline
\end{tabular}

Keterangan : $\left(^{\mathrm{x}}\right)$ Nilai tengah yang diikuti dengan huruf yang sama dinyatakan tidak berbeda nyata pada uji BNT 0,$05 ;{ }^{* *}$; sangat berbeda nyata pada $\alpha=0,05 .\left({ }^{y}\right)$ Perlakuan : Formulasi Cair (f0) : komposisi tepung biomassa spora $40 \mathrm{~g}+$ air $60 \mathrm{ml}$; Formulasi Kering (f1) : komposisi tepung biomassa spora $40 \mathrm{~g}+$ tepung jagung $20 \mathrm{~g}+$ kaolin $20 \mathrm{~g}+$ zeolit $20 \mathrm{~g}$; Formulasi Pasta1 (f2) : komposisi tepung biomassa spora $40 \mathrm{~g}+$ glycerol 1,6 g + Naalginat $1,7 \mathrm{~g}+$ urea $0,2 \mathrm{~g}+$ air 56,5 ml; Formulasi Pasta 2 (f3) komposisi tepung biomassa spora $40 \mathrm{~g}+$ glycelol 9,8 $\mathrm{g}+$ tween- 80 0,01 $\mathrm{g}+$ sukrose 2,39 $\mathrm{g}+$ air 47,8 $\mathrm{ml}$. 
$1,6 \mathrm{~g}+$ na-alginat $1,7 \mathrm{~g}+$ urea $0,2 \mathrm{~g}+$ air $56,5 \mathrm{ml}$ (50,95\%). Kardin dan Priyatno (1996) menyatakan bahwa media dengan kadar gula yang tinggi akan meningkatkan virulensi jamur entomopatogen. Media yang dipakai untuk menumbuhkan jamur entomopatogen sangat menentukan laju pembentukan koloni dan jumlah konidia selama pertumbuhan.

Menurut Pujiastuti et al. (2006) perbedaan viabilitas konidia dapat disebabkan oleh media biakan, suhu dan kelembaban. Pada percobaan ini jumlah konidia yang berkecambah dalam jangka waktu 24 jam setelah inokulasi menunjukkan hasil sangat berbeda nyata. Hal ini disebabkan oleh bahan-bahan pembawa yang ada pada formulasi, terutama formulasi kering $(\mathrm{F} 1)$ yang mengandung media biakan yang sangat baik untuk perkecambahan spora jamur B.bassian, yang terdiri dari tepung jagung, kaolin dan zeolit. Viabilitas spora atau konidia yang berkecambah dapat dicirikan dengan perubahan bentuk konidia yang semula berbentuk bulat menjadi bulat berekor (Gambar 1A).

Hasil percobaan jenis formulasi entomopatogen B. bassiana menunjukkan bahwa beberapa formulasi entomopatogen $B$. bassiana yang diuji berpengaruh nyata terhadap mortalitas hama kutudaun $A$. glycines (Tabel 3). Uji patogenesitas konidia B. bassiana dilakukan untuk mengetahui seberapa besar daya bunuh beberapa formulasi terhadap hama kutudaun $A$. glycines. Hasil penelitian menunjukkan bahwa pada pengamatan 4 sampai 7 hari setelah aplikasi (hsa), pengaruh perlakuan formulasi $B$. bassiana tidak nyata. Sedangkan pada pengamatan 8,9 dan 10 hari setelah aplikasi (hsa) perlakuan formulasi B. bassiana baru berpengaruh nyata terhadap kematian hama kutudaun A. glycines. Kematian tertinggi setiap harinya dapat dilihat pada formulasi kering (F1), yaitu dihari ke-5 setelah aplikasi (21\%), hari ke-6 setelah aplikasi (46\%), hari ke-7 setelah aplikasi (63\%), hari ke-8 setelah aplikasi (79\%), hari ke-9 setelah aplikasi (89\%) sampai dengan hari ke-10 setelah aplikasi (92\%) (Gambar 2).

Purnomo et al. (2012) menyatakan bahwa formulasi yang paling efektif untuk diaplikasikan kepada tiga jenis agensia hayati untuk pengendalian hama pencucuk buah dan penyakit busuk buah kakao adalah formulasi dengan komposisi tepung biomassa spora 40 $\mathrm{g}+$ Tepung jagung $20 \mathrm{~g}+$ Kaolin $20 \mathrm{~g}+$ Zeolit $20 \mathrm{~g}$. Pada percobaan ini formulasi yang paling efektif untuk diaplikasikan kepada hama kutudaun A. glycines Matsumura adalah formulasi kering (F2). Keefektifan jamur entomopatogen dalam mengendalikan hama kutudaun A. glycines sangat tergantung pada kerapatan spora, kualitas media tumbuh, daya kecambah spora dan faktor lingkugan (Purnomo et al., 2012).

Jamur B. bassiana memiliki fase resisten yang dapat mempertahankan kemampuannya menginfeksi inang pada kondisi kering. Keberadaan epizootiknya di alam menyebabkan $B$. bassiana secara cepat menginfeksi populasi serangga hingga menyebabkan kematian. Gejala umum yang terlihat bila jamur B.bassiana menginfeksi serangga adalah gerakan serangga semakin lambat, kemudian diam dan akhirnya mati.

Kematian serangga disebabkan oleh kerusakan jaringan menyeluruh, karena toksin yang diproduksi oleh $B$. bassiana. Hama kutu daun A. glycines yang terinfeksi $B$. bassiana ditandai dengan tumbuhnya miselium berwarna putih pada permukaan luar $A$. glycines, miselium jamur mulai terlihat sejak hari ke-2 setelah kematian serangga uji (Gambar $1 \mathrm{~B}$ dan 1C).

Tabel 3. Nilai tengah mortalitas hama kutudaun A. glycines Matsumura oleh beberapa formulasi jamur entomopatogen B. bassiana

\begin{tabular}{cccccccc}
\hline \multirow{2}{*}{ Perlakuan } & \multicolumn{7}{c}{ Mortalitas A. glycines Matsumura (\%) } \\
\cline { 2 - 8 } & $4 \mathrm{hsa}$ & $5 \mathrm{hsa}$ & $6 \mathrm{hsa}$ & $7 \mathrm{hsa}$ & $8 \mathrm{hsa}$ & $9 \mathrm{hsa}$ & $10 \mathrm{hsa}$ \\
\hline Formulasi Cair (F0) & 6 & 15 & 30 & 47 & $54 \mathrm{~b}$ & $57 \mathrm{~b}$ & $59 \mathrm{~b}$ \\
Formulasi Kering (F1) & 5 & 21 & 46 & 63 & $79 \mathrm{a}$ & $89 \mathrm{a}$ & $92 \mathrm{a}$ \\
Formulasi Pasta1 (F2) & 3 & 12 & 30 & 46 & $56 \mathrm{~b}$ & $60 \mathrm{~b}$ & $62 \mathrm{~b}$ \\
Formulasi Pasta2 (F3) & 5 & 15 & 32 & 56 & $64 \mathrm{ab}$ & $73 \mathrm{ab}$ & $77 \mathrm{ab}$ \\
\hline Pr F & $0,740^{\text {tn }}$ & $0,311^{\text {tn }}$ & $0,113^{\text {tn }}$ & $0,196^{\text {tn }}$ & $0,046^{*}$ & $0,013^{*}$ & $0,015^{*}$ \\
\hline BNT & & & & & 18,466 & 19,181 & 20,478 \\
\hline
\end{tabular}

Keterangan : Nilai tengah yang diikuti dengan huruf yang sama dinyatakan tidak berbeda pada uji BNT 0,$05 ;{ }^{\text {tn }}$; Tidak berbeda nyata pada $\alpha=0,05$; BNT 0,$05 ; *$; Berbeda nyata pada $\alpha=0,05$; hsa $=$ hari setelah aplikasi. 


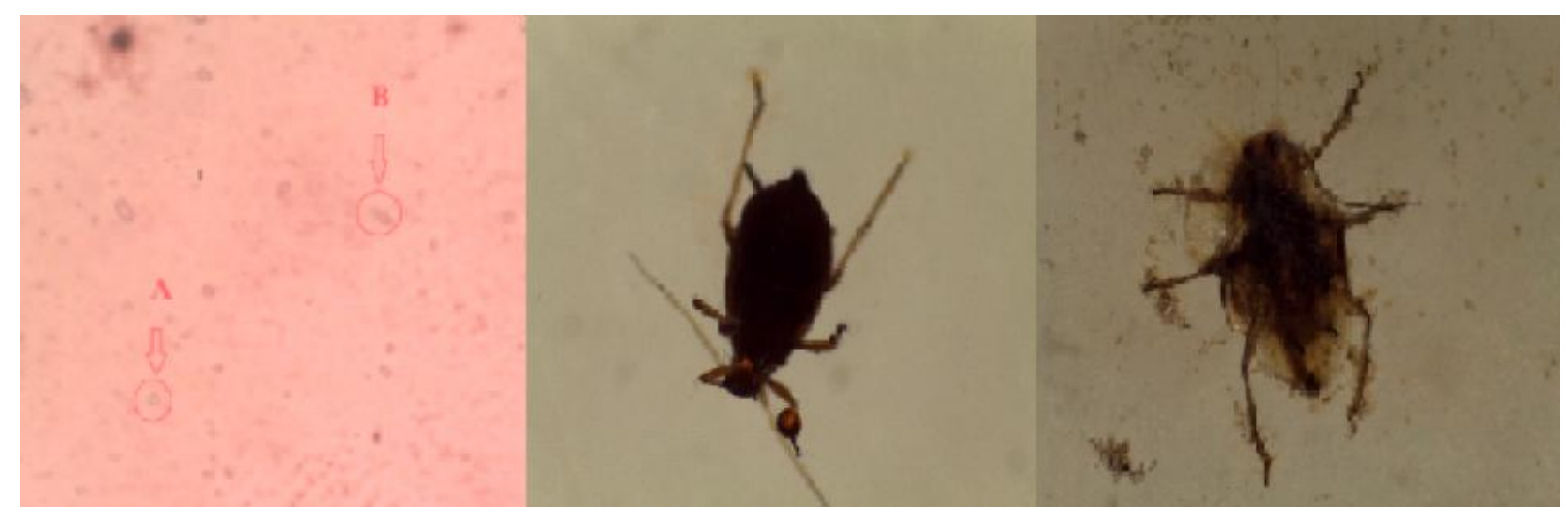

Gambar 1. (A) Perkecambahan konidia jamur B. bassiana formulasi kering pada perbesaran (10 x 40): A. Konidia belum berkecambah; B. Konidia berkecambah. (B) Serangga kutu daun A. glycines Matsumura yang tidak terinfeksi jamur B. bassiana (C) Serangga A. glycines Matsumura yang terinfeksi jamur B. bassiana pada perbesaran (10 x 40).

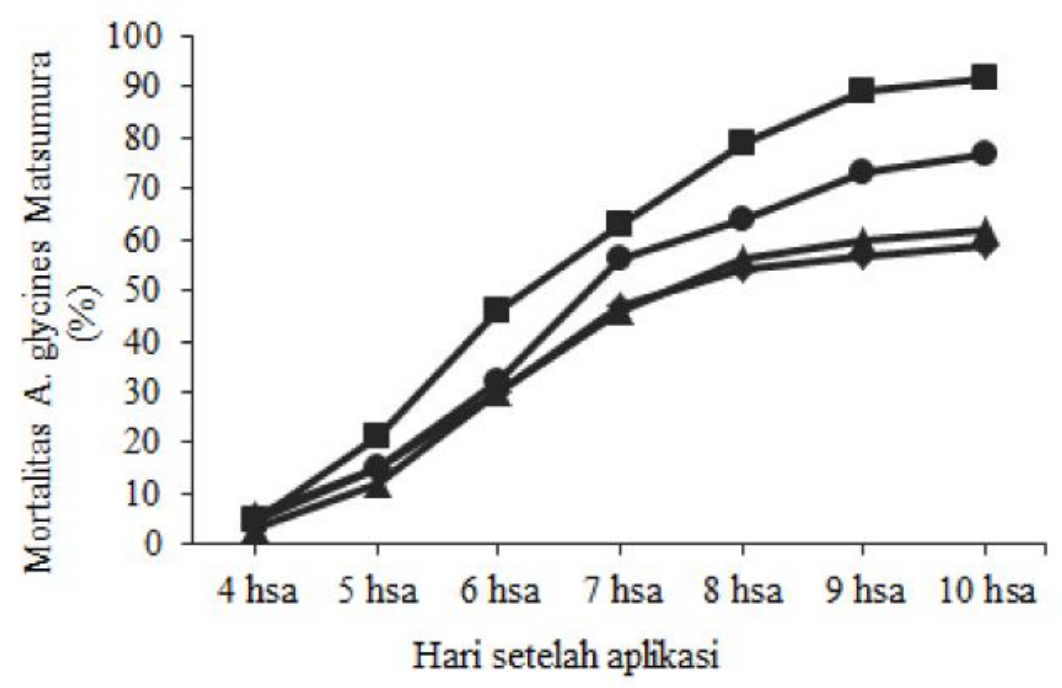

Gambar 2. Grafik mortalitas A. glycines dari hari ke-4 setelah aplikasi sampai hari ke-10 setelah aplikasi; Formulasi Cair (F0) : Komposisi tepung biomassa spora $40 \mathrm{~g}+$ air $60 \mathrm{ml}$; Formulasi Kering (F1) : Komposisi tepung biomassa spora $40 \mathrm{~g}+$ tepung jagung $20 \mathrm{~g}+$ kaolin $20 \mathrm{~g}+$ zeolit $20 \mathrm{~g}$; Formulasi Pasta1 (F2) : Komposisi tepung biomassa spora $40 \mathrm{~g}+$ glycerol 1,6 $\mathrm{g}+$ na-alginat $1,7 \mathrm{~g}+$ urea $0,2 \mathrm{~g}+$ air 56,5 ml; Formulasi Pasta2 (F3) Komposisi tepung biomassa spora 40 $\mathrm{g}+$ glycerol 9,8 $\mathrm{g}+$ tween-80 0,01 $\mathrm{g}+$ sukrose 2,39 $\mathrm{g}+$ air 47,8 ml.

\section{KESIMPULAN}

Kerapatan konidia B.bassiana berbeda nyata antarformulasi yang diuji. Kerapatan konidia B.bassiana formulasi cair (F0) lebih tinggi dibandingkan formulasi pasta-2 (F3) dan formulasi pasta1 (F2). Namun, formulasi cair (F0) tersebut tidak berbeda nyata dengan formulasi kering (F1). Viabilitas konidia B.bassiana berbeda nyata antarformulasi yang diuji. Viabilitas konidia B. bassiana formulasi kering (F1) lebih tinggi dibandingkan formulasi pasta1 (F2), formulasi cair (F0) dan formulasi pasta2 (F3). Aplikasi B.bassiana dengan formulasi kering (F1) menyebabkan mortalitas kutudaun tertinggi $(92 \%)$ dibandingkan formulasi cair (F0), formulasi pasta1 (F2) dan formulasi pasta2 (F3).

\section{DAFTAR PUSTAKA}

Deciyanto, S dan Indrayani, 2007. Status teknologi dan prospek Beauveria bassiana untuk pengendalian serangga hama tanaman perkebunan yang ramah lingkungan. J. Litbang Pertanian, 17(2): 29-46.

Ekawati, A.S., A. Nasrudin, dan N. Amin., 2013. Penekanan Populasi Aphis glycines (Homoptera: Aphididae) oleh Cendawan Entomopatogen 
Beauveria sp., Trichoderma sp., Paecilomyses sp., dan Fusarium sp., pada Tanaman Kedelai di Greenhouse. Tersedia: http://www.unhas.ac.id / pertanian/index 2.php? option $=$ com_docman\&task=doc_view $\&$ gid $=747 \&$ Itemid=75, [Tanggal 6 Mei 2014].

Eyal, J., J.F. Walter, L. Osborne, dan Zdenek, L. 1994. Method For Production and Use of Phatogenic Fungal Preparation For Pest Control. US. Patent No.5, 360, 607. Nov. 1, 1994.

Hasyim, A., H. Yasir dan Azwana. 2005. Seleksi substrat untuk perbanyakan Beauveria bassiana (Bals.) Vuill. dan infektivitasnya terhadap hama penggerek bonggol pisang, Cosmopolites Sordidus Germar. J.Hort.15:116-123.

Herlinda, S., 2008. Efikasi bioinsektisida formulasi cair berbahan aktif Beauveria bassiana (BALS.) vuill. dan Metarhizium sp. pada wereng punggung putih (Sogatella furcifera HORV.). Seminar Nasional dan Kongres PATPI. Palembang, 1416 Oktober 2008. $15 \mathrm{hlm}$.

Kardin, M.K. dan T.P. Priyatno. 1996. Pemanfaatana cendawan Hirsutella citriformis Untuk pengendalian wereng coklat (Nilaparvata lugens Stal.). Dalam: Temu Teknologi dan persiapan Pemasyarakatan Pengendalian Hama Terpadu. Lembang, 27-29 Mei 1996. 25 hlm.

Malau, M., A. Sopian, dan Yusriadi. 2010. Pengujian jamur Beauveria bassiana (BALS.) Vuill. isolat asal Banjar Baru dalam menekan perkembangan hama tanaman. J. Agroscientiae, 17(2): 101-105.
Morales, E. dan H. Rochling., 1998. Water Dispersible Granules of Spore or Live Beauveria bassiana. US Patent 5, 730, 973, Mart 24, 1998.

Prayoga, Y., 2006. Upaya mempertahankan keefektifan jamur entomopatogen untuk mengendalikan hama tanaman pangan. J. Litbang Pertanian 25(2): 47-54.

Pujiastuti. Y., Erfansyah, dan S. Herlinda., 2006. Keefektifan Beauveria bassiana (BALS.) Vuill. isolat indigenous Pagaralam Sumatera Selatan pada media beras terhadap larva Plutelle xylostella Linn. J. Entomol Indonesia 3(1): 3040.

Purnomo, T.N. Aeny, dan Y. Fitriana. 2012. Pembuatan dan aplikasi formulasi kering tiga jenis agensia hayati untuk mengendalikan hama pencucuk buah dan penyakit busuk buah kakao. Laporan Penelitian Hibah Bersaing. Bandar Lampung.

Quimby, P.C., A.J. Caesar, L.J. Birdsall, C.D. Boyette, N.K. Zidack, dan W.E. Grey. 2002. Granulate Formulation ang Methode For Stabilizing Biocontrol Agents. US Patent No. 6,455,036 B1. Sep.24, 2002.

Suwahyono, U dan P. Wahyudi. 2008. Produksi dan formulasi bioinsektisida dari propagul aktif jamur Beauveria bassian. J. Tek. Ling 9(1): 85-91.

Suwahyono, U. 2010. Cara Membuat dan Petunjuk Penggunaan Biopestisida. Penebar Swadaya. Jakarta. 164 hlm. 